\title{
Radio Gema Edukasi Streaming as A Learning Resource : A Literatur Review
}

\author{
Marieska Nurulia Srikandini ${ }^{\mathrm{a}}$, Eusoff Yendo Afgani ${ }^{\mathrm{b}}$, Eko NSL Pitoy $^{\mathrm{c}}$ \\ a marieskasikom@yahoo.com \\ ${ }^{a}$ Education and Culture Office of Lampung Province, Jl. Drs. Warsito 72 Bandar Lampung 35215, Indonesia \\ ${ }^{b}$ Taman Sri Pulai Skudai Johor 81300, Malaysia \\ ${ }^{c}$ Sun Education Lampung, Jl. P. Antasari 47 Bandar Lampung 35121, Indonesia
}

\begin{abstract}
Radio broadcast is one of the media that can be utilized as a learning source. Educational radio program can be targeted not only to the teachers but also to audience in general. The technology advancement has made it possible for internet based audio, known as streaming radio, in which the programmes are accessible from the computer hardwares connected to the internet connection or via the mobile phones without relying on any radio receiver set. This research aim on the discourse of literatures on streaming-based educational program of Radio Gema Edukasi as learning resource that is based on radio broadcasting books and reasearch journals, learning materials or learning media, as well as radio programmes as learning media from year 1978 to 2000 . The reference literatures point out that radio broadcasts possess numerous advantages as a learning media. The broadcast from the Radio Gema Edukasi is applicable as a learning resource due to the fact that the delivered learning materials have been designed to suit with the needs of the target students, teachers, and educational -concerned societies. The broadcast has given an independent and virtual study experience to the students; as it allows the access to accurate and novel information regarding the educational matters; as well as to provide solutions related to educational issues.
\end{abstract}

Keywords: educational radio, streaming radio, learning resource.

\section{Introduction}

Learning is a mental activity (psychist) that results changes a relatively constant change. (Isti'adah, 2020:12) that has been an interactional process towards all sort of situations around the students (Rusman, 2017:1). Learning is a concious effort done well planned, sistemized, with certain methode in order to alter static behaviour through interactions with learning resources (Sitepu, 2017:18). Robert. M. Gagne also adds that learning is a mean done by teachers, intructors, learners with the aim to facilitate students learning easily (Hastuti, 2015). Gagne defines that learning is a change in one's ability after a constant study, not only because of growth process (Warsita, 2008). The process of learning takes place because of one's interaction with learning resource or the environment that brings changes in attitudes. According to Gagne's learning theory, learning abilities include intellectual abilities, cognitive strategies, verbal information, motor skills, and attitudes. There are internal learning conditions that arise from students' memory as a result of previous learning and students' external conditions that need to be considered by educators. This external condition, if properly regulated and managed, is an attempt to learn. For example the use or use of various media and learning resources.

Learning resources are data, individuals, and/or matters that enable students to study (Ely, 1978:3). Learning resources in general scope are any kinds of sources outside a person or study participants that make 
it possible or more accessible for the learning process to take place (Rohani, 2014:102) on oneself or students (Rusman, Kurniawan dan Riyana, 2012:42). Perceival dan Ellington (1984:125) mentions that an effective learning resource should meet three criterions: available in short periode of time, trigger students' self motivation, and is able to fulfill the students needs to learn independently.

\section{Methodology}

The following composition is a literature discourse on educational streaming broadcast of Radio Gema Edukasi as a learning source that refers to research books and journals focusing on radio broadcast, learning resources or learning media, and radio broadcast as learning media from year 1978 to 2020.

\section{Educational Radio Broadcast}

One of the media available to utilize in learning processes in radio broadcast programe. Radio is an auditive media no matter what means to access. The specific feature of the radio is placed on the sound makes it possible for limitless imagination or as it is known as "Radio is Theatre of Mind" (Prayudha dan Munaf, 2013:iv)

Radio bears abundant pluses as to use as learning media namely: its price is relatively cheap, has more various programs compare to to the television, is as as well mobile; when it is paired along with a radio recorder the users can replay the recording anytime they wish; radio is able to develop one's imagination, it arrouses the listeners' active participation, radio can also make the listeners to focus on certain words, on the sounds and its meaning; sound broadcast has been proven to be suitable to teach music and language or others; radio could presnt the class with teachers on their respected expertise that could cater the problem with number of teachers availability; lessons delivered from the radio might be better in terms of quality both from the scientific point of view and method; radio is able to present on the spot reports, actual broadcasts that can contribute to novelty (immediciacy) on parts of topic; radio could present the foreign experiences to the class rooms; anda radio could cut down the time and space boundaries and its reach is enormously wide (Sadiman et.al, 2012). Radio, on the other side, can not engage a spontaneous interaction; the listeners can not to be controled to be active; low competency in understanding sophisticated messages caused by the limitation of human's hearing compare to sight; it is one way communication; no feed back from the listeners (Rohani, 2014:94).

Educational radio is a radio that airs education contents with the aim to establish a learning atmosphere and a learning process to take place to make the students actively develop their personal quality to get religious spiritiual strength, self control, personality, inteligence, noble nature and skills for theirselves, society, nation and country (Innayah, 2015). Educational radio possess its own value, for such providing up to date information, interesting for the audience, wide in range, fact-based, boosting creativity, and containing recreational values (Danim, 2008:20).

The practice of radio broadcast for learning process has been applied by many developed countries for years. The commercial and educational stations in the US have accepted lisence to produce class broadcasts since the 1920's. This was then supported by national network in order to provide educational programmes. Most programmes were in line with school lessons. Then, Scandinavian countries and later England founded special departement for educational programmes around the late 1920's or 1930's. Generally, such programmes followed the curriculum thoroughly. Yet, a study on the use of radio in the class room in Sweden revealed that there were differences between the regular school book contents with the radio contents. The radio programmes put the focus on contemporary progressive ideas about education and progressive political thinkings that are unbale to be presented in school books in that era (Lindgren, 2008). This matters indicate that radio is able to invite occurances or events from the outside world into the class room. 
Radio as educational media has been started well by both government and private bodies, such Nicaragua's math radio project in mid 1979 done by Stanford University under the contract of United States Agency for International Development (USAID). In addition there was also rural radio broadcast and kelompencapir ( kelompok pendengar, pembaca dan pirsawan = group of listeners, readers and audience) broadcasted during the regim of President Suharto (Adning dan Raisal, 2014). To add more, the methodology applied in Nicaragua has been broaden up and was adapted for students of all ages for the mathematics learning in Bolivia and Thailand, science lessons in Papua New Guinea, English in South Africa, early childhood development in Bolivia and Nepal, basic grown up education in Honduras, as well as some other countries. Each cases was specially crafted by experts from the particular countries in order to grasp the students' interest and in order to reach learning goal of each specific area (Bosch, 1997).

The educational radio broadcast in Indonesia, specifically in central Java, took as start when the Ministry of Education and Culture Affairs launched it on February 16, 1977. The programme was specially aimed for the elementary school teachers as an answer for levying the the education in Indonesia on the grounds of equal learning opportunities, education system and management enhancement and better teaching quality. The reasearch result indicated that the the broadcast did contribute a positive outcome on the elementary school teachers competence that contributed to $100 \%$. The quality of educational radio broadcast will contribute to the increase of the particapants elementary school teachers' quality as much as $43 \%$. The education broadcast contributed $18 \%$ to the variation of the competency of the elementary school teachers that participated in the broadcast (Rohani, 2014:88).

The educational radio broadcast is not only for the teachers. There are a lot of radio broadcasts with educational mission and are aimed for listeners in general. The content is not only covering class room lessons but also contents which are more edutainment in concept or a learning concept with entertainment elements for more condusive and fun learning experience.

\section{Streaming Radio}

Knowledge, technology, and arts have developed rapidly, such growth is then spread throughout various electronic and internet based media. The internet has been an inevitable requirement for these days' primary needs. The internet as a source of information has been proven to serve a much faster, affordable, effective, efficient and practical access in the scope of education, entertainment, as well as the general knowledge. The presence of the internet has also given countless effects not only to the printed media but also the broadcast media both radio and television.

The radio broadcast transmited through broadcast wave length is transformed into a broadcast with the interent technology. Such convertion is what it is then known as streaming. Streaming itself is a multimedia process that is continuously accessible provided by content providers for end users by sending playback audio or in real time manner (Djamal dan Fachruddin, 2011:40). Streaming media as a learning resource is more advance than the conventional one for streaming serves as a powerfull yet flexible tool for both parties of students and teachers (Shephard, 2002). For this reason, the teachers and the students are required to have proper skills, devices, and infrastuctures in order to fully use the streaming media to encourage the students to be more self reliance and responsible towards their own learning process.

Digital radio or streaming radio is means of technology that sends information via digital signal Radio (Prayudha dan Munaf, 2013:98). Digital radio comes with numbers of plusses for instance clearer sound than the analog one, better signal quality, and features such as pause, rewind, or save for latter to listen. The listeners have to no longer listen the broadcast from a radio set, they can also enjoy the broadcast from the computers that is connected to internet connection or they can access it from application in their mobile phone. The streaming radio could reach wider range of listeners because it is based on internet service that has global audience span. Thus, it is quite contradictive with the conventional radio broadcats that owns limited range for the cause of its limited broadcats wave length (Prasetya, 2016). Everybody has the access to any 
content including learning matters through the educationla radio streaming.

\section{Educational Radio Streaming as A Learning Source}

Radio Gema Edukasi is one of educational media developed by the Office of Information Technology and Communication of Education and Culture Affair Division as the regional operational operator the Office of Education and Culture Affairs of Lampung Province, Indonesia. The broadcast is conducted on streaming base at www.radiogemaedukasi.net and www.disdikbud.lampungprov.go.id with the purpose to be means to facilitate learning process and as an alternative reference source for both teachers and students. The programme is in the form of audio with a fun approach in order to support the better, more robust and more competitive quality of education to head for an intelectual and ethical society.

Radio Gema Edukasi airs every Monday to Friday at 09.00 AM to 09.00 PM with the following programmes Pena Si Budi, Seputar Dunia Pendidikan, Apresiasi Sastra, English Audio Dictionary, Kisah Tokoh, Dongeng Rakyat, RE Musisi, Risalah Nabi dan Sahabat, Ensiklopedi Populer, Kata Mutiara, Intermezzo, Asal Usul, Hikmah di Balik Kisah, and Bimbingan Belajar. The programmes are under the production of the Office of Information Technology and Communication and the Office for the Development of Education and Culture Radio of Yogyakarta, the Ministry of Education and Culture Affairs of the Republic of Indonesia.

Character building for children and national pride, to take samples from the Indonesian national heroes and figures and successful people is presented in the programme Pena Si Budi, folklore and stories of notable figures. Students of elementary school, junior high, and also senior high can improve their lesson mastery if they keep abreast on Bimbingan Belajar on school subjects. Students and people in general can widen up their general knowledge by listening to Ensiklopedi Populer or knowledge on various daily things packed in a musical programme Intermezzo. Radio Gema Edukasi broadcast also serves motivational materials presented in words of sayings in Kata Mutiara as an additional programme. The programme of Apresiasi Sastra introduces the listeners to Indonesian literatures while RE musisi discusses the career of Indonesian legendary musicians as a form of appreciation towards local literature and music.

The presence of Radio Gema Edukasi has presented an alternative in coping with commercial base radio and media that do not really focus on broadcasting educational contents. The contents of Radio Gema Edukasi has been crafted to deliver educational messages as it is expected to be made use as a learning resource for the teachers and students. Radio Gema Edukasi has also met its function as a learning resource: raising educational productivity; enables individual education; makes instant study possible; provides scientific foundation for learning; provides a broader educational presentation with the use of a media; radio is easy, practical, economical, flexible, and appropriate for the goal. For all of the mentioned reasons, the broadcast of Radio Gema Edukasi has also put consideration on suitable contents or broadcast materials supply as well as arranging its distribution on air time that is appropriate with the characters of the target audience of students, workers, or public in general. The listeners are expected to add more knowledge and information so that they are able to self educate as well as educate others by acccessing various educational contents or materials presented in a regular and intensive manner.

The streaming broadcats of Radio Gema Edukasi is a radio broadcast model that has been used as creative effort in spreading educational contents or materials to public in all over Indonesia and abroad easily with all of its possible drawbacks and advantages. The main drawback of the broadcast of Radio Gema Edukasi is it lacks of direct feed back. The information wholesomeness, personal identity, interaction and integrity not to mention entertainment in listening to the streaming radio are constructed by the perception in the listeners' (audience) mind from the stimulus, registration, and interpretation which are represented by streaming radio. Such perception will then result a feed back that serves the audience satisfaction in listening the streaming radio (Jati dan Herlina, 2013). 


\section{Conclusion}

Based on literatures and studies used as references for this composition, it is indicated that radio broadcasts do share positive outcomes to use as a learning media. The broadcast of Radio Gema Edukasi has accomplished the requirement as an effective learning source based on Perceival and Ellington criteria. The broadcats of Radio Gema Edukasi could serve as a learning source for the fact that the aired learning materials has have been tailored as what the students, teachers, and public that shares attention towards education need; it has served the students an independent and virtual learning experience; shares accurate and novel information on education world; has assited in solving the problems in education.

\section{Recommendation}

- The educational radio broadcast is possible to be used as an alternative learning media for students.

- There should be a proper needs analysis mainly in public empowerment in order to produce interesting, intertaining and in the same time educating contents or materials.

- Annual evaluation should be programmed to the educational content or material broadcasted streaming from Radio Gema Edukasi, this to find out the audience's responses on what needs to be provided in regards the needs of the public.

- Information Technology and Communication of Education and Culture Office - Education and Culture Office of Lampung Province ought to take a serious, focused-care, couregous move and appropriate break through to get the public's attention on the broadcast of Radio Gema Edukasi.

- Radio Gema Edukasi needs to socialize itself to various related institutions and organizations (educational foundation, schools, societies) and printed, online and offline mass media promotional programms by conducting events in schools also joining any education exhibitions and events held by the government.

- Radio Gema Edukasi must keep on advancing its cooperation network with numerous education stake holders in order to make its content optimally absorbed both within the school and outside the school environment.

\section{References}

Adning, Mohamad., Raisal, Yessi Aprilia. 2014. Suara Edukasi: Media Pembelajaran yang Mencerdaskan, Merakyat dan Bersahabat. Jurnal Teknodik 18-2, p. 133-143.

Bosch, Andrea. 1997. Interactive Radio Instruction: Twenty-three Years of Journal Improving Educational Quality. Education and Technology Technical Notes Series, 2-1, p. 1-11. Source: https://documents1.worldbank.org/curated/en/321401468782370378/ pdf/multi-page.pdf (Accessed: 28 May 2021).

Danim, S. 2008. Media Komunikasi Pendidikan. Jakarta: Bumi Aksara, p. 20.

Djamal, H. dan Fachruddin, A. 2011. Dasar-Dasar Penyiaran: Sejarah, Organisasi, Operasional, dan Regulasi. Jakarta: Kencana Pranada Media Group, p. 40.

Ely, Donald P. 1978. Book of Reading Instructional Technology Caster for Instructional Development. Washington DC: Syracuse University, p. 3.

Hastuti, Dian Nur Antika Eky. 2015. Pengaruh Model Pembelajaran AIR (Auditory, Intellectually, Repetition) dan TPS (Think Pair Share) terhadap Prestasi Belajar Sejarah Ditinjau dari Kecerdasan Emosional Siswa Kelas X di Sekolah Menengah Atas (SMA) Negeri Ponorogo. Surakarta: Universitas Sebelas Maret. Thesis.

Innayah. 2015. Survai Pendengar Terhadap Konten Siar Radio Pendidikan. Jurnal Teknodik, 19 - 3, p. $283-292$. 
Isti`adah, Feida Noorlaila. 2020. Teori-Teori Belajar Dalam Pendidikan. Tasikmalaya: Edu Publisher, p.12.

Jati, R.P. dan Herlina, M. 2013. Hubungan antara Radio Streaming dengan Persepsi dan Kepuasan Audiens di PT. MNC Skyvision Jakarta. Jurnal Komunikasi ASPIKOM, 2-1, p. 589-602. Source: http://www.ejurnal.com/2016/04/hubungan-antararadiostreaming-dengan. html (Accessed: 13 November 2019).

Lindgren, Anne-Li. 2008. Radio. http://www.faqs.org/childhood/Pa-Re/Radio.html (Accessed: 28 May 2021).

Prasetya, M.Y. 2016. Radio streaming, babak baru penyiaran radio. Sumber: https://www.merdeka.com/khas/radio-streaming-babakbaru-penyiaran-radio-bisnis-radiodigital-1.html (Accessed: 13 November 2019).

Perceival, Fred., Ellington, Henry. 1984. Teknologi Pendidikan, Diterjemahkan oleh: Sudjarwo. Jakarta: Erlangga, p. 125.

Prayudha, Harliantara Harvey., Munaf, Andi Rustam. 2013. Radio is Sound Only, Pengantar \& Prinsip Penyiaran Radio di Era Digital. Jakarta: Broadcastmagz, p. 98.

Rohani, Ahmad. 2014. Media Instruksional Edukatif. Jakarta: Rineka Cipta, p. 94.

Rusman. 2017. Belajar \& Pembelajaran: Berorientasi Standar Proses Pendidikan. Jakarta: Kencana, p. 1.

Sadiman, Arief S, et.al. 2012. Radio dan Media Teknologi Sebagai Media Pendidikan; Pengertian, Pengembangan, dan Pemanfaatannya. Jakarta: PT Raja Grafindo Persada, p. 50.

Shephard, Kerry. 2002. Streaming Audio and Video for Course Design. LTSN Generic Centre Starter Guide, p. 1-5. Source: https:// www.alt.ac.uk/sites/default/files/assets_editor_uploads/documents/eln013.pdf (Accessed: 28 May 2021).

Sitepu, BP. 2017. Pengembangan Sumber Belajar. Jakarta: Rajagrafindo Persada, p.18.

Warsita, B. 2008. Teori Belajar Robert M. Gagne dan Implikasinya Pada Pentingnya Pusat Sumber Belajar. Jurnal Teknologi Pendidikan, XII-1 ,p. 64-78 